the animal with snow shoes." In June, one was captured, and the Doctor named the species Lepus bairdii. The animal seemed limited to that small Alpine territory. But one specimen was secured, and no more was heard of this hare until 1872 , when Dr. Hayden and party were in that region in the months of August and September. At this time five specimens of Baird's hare were obtained by Mr. C. Hart Merriam, the naturalist to the Hayden Survey. Of these four were adult males, and all had large teats and udders full of milk. The hair round the nipples was wet, and stuck to them, showing that they had just been suckling their young. To make all certain, resort was had to dissection, when the sex was demonstrated. Not only did Mr. Merriam make dissection, but also Dr. Josiah Curtis, a naturalist of the United States Geological Survey, with the same result. In the face of such testimony disbelief would seem discourtesy."

\section{NOTES FROM THE LETTERS OF CAPIAIN DAWSON, R.A., IN COMMAND OF THE BRITISH CIRCUMPOLAR EXPEDITION ${ }^{1}$}

Fuly 30, Fort Chipewyan, on Lake Athabasca

A FTER practically incessant travel since leaving Eng$A$ land, at last I find myself condemned to a week's rest, as there are no boats going to Port Rae until the Mackenzie River boats return. But here we are in the lap of luxury ; we get bread, butter, and milk, which we have not tasted for ages, to say nothing of the novel experience of sleeping under a roof and on a bed. I have had a most delightful journey, but it all seems like a dream to look back to: my memory is a kaleidoscope of pine trees, rapids, lakes, and golden sunrises and sunsets. Down stream we travel day and night. At sunset the boats are lashed together, and then the crew go to sleep. It is very nice drifting down in the silence amongst the pines, but:bed-time comes at last. I then roll myself in a blanket, lie down, and look at the stars till I fall asleep. At sunrise I wake to find the crew on the shore, boiling their kettle, and a cup of tea is very refreshing. My blanket and my hair, too, I find dripping wet with dew when I wake.

At noon or so we land, and cook more tea, and make breakfast usually off pemmican, which is composed of buffalo flesh dried and pounded, and put in a leather bag with grease poured over it. It is not nice, but it supports life. When we have such a luxury as flour, it is baked into cakes in a frying-pan. We get into the boat again, and eat our breakfast whist drifting down stream. Byeand-bye the current becomes more rapid, and at last we see the river disappearing in a cloud of spray. Here is a Portage, so the boats pull to shore and the cargo is landed. The crew then return. I take my place in the boat, and after each man has laid aside his pipe, settled himself in his seat, and got a good grip of his oar, we shove off and dash into the rapid as fast as twelve oars can take us, with shouts of "Hurrah ! boys!" (the only English words the Indians know) and "ekwa," a Cree word, meaning "Come on." The guide or steersman stands on a seat in the stern steering the boat with a long oara picturesque figure, with his long black hair waving behind him. In a moment we are among the rapids, and seem to sink into a mass of foam, from which we emerge sideways, and are carried towards a projecting rock. Wild exclamations in French from the guide! the bow oarsman seizes a pole, and sends the boat off, and then we spin down the tail of the rapids, not without one or two bumps that make the whole frame of the boat quiver. The whole distance, a mile or two, is done in two or three minutes, and it is not bad fun. After the boats have run the rapids it is dinner-time, and then the crew set to work to carry the cargo over the portage--a work of two or three hours. In some places the boats a Continued from p. 105. themselves have to be hauled across on rollers, which is pretty hard work. We continue our way down stream, stopping about 4 o'clock for tea, and at sunset reach another Portage. Here we camp, and in a very short time the tents are pitched, a tree felled to make a camp-fire, and kettles singing thereon. Supper and bed-time make up the day. Such is a fair specimen of a day's river travelling. With a fair wind we sail, especially on the lakes.

The crews are Chipewyans; their language is chiefly made up of clicks and gurglings in the throat, and differs altogether from. Sioux, Cree, and the other languages spoken further south.

A Roman Catholic priest here showed me a Chipewyan grammar and dictionary that they have composed. There are over sixty sounds in the language, so they have to invent additional letters. There is something Asiatic in the appearance of these Indians, with their small moustache and tufts of hair on their chin, quite unlike the Indian of the plain. They are Roman Catholic.

After leaving Portage la Loche, on July 24, the first day's journey took us down to the Terre Blanche falls; here we had to haul the boats over a small hill, as the river is a succession of falls and rapids for about half a mile; a very pretty place, the river runs between limestone cliffs, crowned with pine trees, and all stained bright orange colour with lichen.

On the 28th we reached the Athabasca, a splendid river, usually half a mile in width, sometimes more. Its course is pretty straight to the north, so we often had a view of some fifteen miles or so down the valley.

On the 29 th, having a fair wind, we made a hundred miles. We met two lots of Indians ; from the first we got some moose, the first fresh meat we had tasted for a long time, and from the others we got some raspberries and asketoon berries, which were very refreshing.

As we drifted down the river, the pines began to give place to poplar, the poplar to willow, and the willow to reeds, till at last we saw Lake Athabasca before us, a rocky coast to the north, and to the east water as far as the eye could reach.

A fresh breez took us across the lake in two hours, and we received a hospitable welcome at this place, together with all sorts of luxuries that had become quite strange to us.

This is quite a large place; there are about a dozen houses, two churches, two bishops, a sisterhood, and some missionaries. The country is rocky, and most desolate. To the south and west the great lake stretches away to the horizon, and the land view is composed of hills of reddish granite, no soil, plants growing here and there out of occasional crevices, and a few stunted firs scattered about. There are woods in the valleys, but the trees are of no size. No sound breaks the stillness but the weird cry of the loon, a sort of maniacal laugh that is almost a wail ; and the solitude is heightened by the reflection, that for 1000 miles north, south, east, and west all is wilderness.

Towards the lake the view is pretty, as there are many islands covered with pines.

The weather is cooler than it has been, I am glad to say. For days we had the thermometer at $85^{\circ}$ and $86^{\circ}$, and even higher; but though hot, the summers are short, and I think that of this year is over. The mosquitos, at any rate, are beginning to disappear, and now the climate is nearly perfect, like the best English summer weather.

August 5.-There was a fine aurora last night: a curtain of flame seemed to descend from the sky nearly overhead and right across the sky, and after waving about for a few moments, died away again. Yesterday I went to see the Roman Catholic Mission; they have quite a pretty church, which has been built some thirty years. I was also taken to see the sisters, of whom there are six. They all seemed very flourishing, and have a very nice house. 
August 6, Sunday.-I was at the English church this morning. It is a nice little church, and there was a congregation composed of the Hudson's Bay people, twenty or thirty. Most of the Hudson's Bay people are Scotch, many coming from the Orkneys. The Bishop Bompas is very pleasant, he is a great traveller, and has lived amongst the Esquimaux at the mouth of the Mackenzie River, and he works very hard.

August 9.- The weather has been stifling hot, $89^{\circ}$ indoors, for the last three days, quite like the West Indies. Yesterday I went over to see a performance at the Roman Catholic Mission of the school children, got up by the sisters in our honour. They sang, and acted, and danced remarkably well. They have very good memories I am told.

It is curious living together without money, as one does in this country. Everything is done by barter, the unit of value being a skin; the average value of a beaver skin is said to be worth twenty ducks, or forty white fish, or twenty plugs of tobacco, so that for a plug of tobacco (about an $\frac{1}{2} \mathrm{oz}$.) one can get a duck or two white fish, a large fish about two feet long, and very good eating. This place, like all other habitations in the north-west, swarms with large wolf-like dogs. These are used in winter for drawing carrioles, and a team of four dogs will draw 500 lbs. or more. The Indians use them too, in summer, as pack animals.

The boats have just made their appearance, four black specks on the horizon to the north, so we shall be off in a few hours.

\section{THE SWEDISH EXPEDITION TO SPITZBERGEN, 1882}

THE results of the researches of the expedition de1 spatched to Spitzbergen last summer by the Swedish Academy of Sciences, under the eminent savants Baron G. de Geer and Dr. Nathorst, for the study of the geological and geographical features of the island, are very interesting. In the first instance, these gentlemen have drawn two maps, showing the exact geographical features of the island, as compared with those prepared by two previous expeditions. Of these, one shows the outlines of the fjords and valleys in the southern part of the island, with the boundary of the inland ice, and the other the relative depth of the seas around Spitzbergen and Scandinavia. From the latter it appears, that these two land-formations are really elevated ridges on a comparatively level plateau, which sinks abruptly in the ocean west of Spitzbergen. In the second instance, the expedition has ascertained that the deep fjords and narrow valleys of the island have not been formed by upheaval of the terrestrial crust or by strong water-courses, but are due to the action of glaciers during the Glacial period, while from the marks on the rocks of the Beeren Island, it may be assumed that the Spitzbergen glaciers extended even so far.

At the close of the Glacial period a sudden subsidence, followed by a still greater rising of the shores, both of Spitzbergen and Scandinavia, most probably took place, which is demonstrated by the discovery, in Scandinavia as well as Spitzbergen of old gravel beaches and the shells of salt-water mussels far inland. The existence in Spitzbergen of some of the most characteristic species of the Scandinavian flora and fauna, may perhaps be explicable by migration from Scandinavia, at a period when the plateau between the two ridges was above the level of the sea, we may assume, shortly after the close of the Glacial period. It seems impossible to explain otherwise how, for instance, birds, particularly those living on land, could have found their way to this island, some 700 miles distant from the Scandinavian peninsula.

At the same period, the common Scandinavian "Blaamusling," Mytilus edulis, and a few other species have, no doubt, also migrated into the island. This species is now, however, extinct, but the large quantities of shells found on the shores indicate that at one time it must have been common enough. The latter circumstance seems to prove that the climate of Spitzbergen at an earlier period was much milder than at present, and corroborates also the theory of a connection having existed between Spitzbergen and Scandinavia about the Glacial period, as such a land-barrier would have caused the eastern arm of the Gulf Stream, which now flows by the North Cape. to have taken a more northerly direction, and thus carried the softening elements of a southern clime to the now desolate rocks in the Arctic Ocean.

\section{THE INCREASE IN THE VELOCITY OF THE WIND WITH THE ALTITUDE}

$T \mathrm{HE}$ fact that the upper strata of the atmosphere as a rule move more rapidly than those near the earth's surface, has long been inferred on theoretical grounds, though little direct evidence beyond the marvellous and often unexpected voyages of aëronauts, or casual observation of the clouds, has hitherto been furnished in its favour. The prectical value of this fact is beginning to be felt by engineers since the investigations undertaken by Mr. T. Stevenson in 1876, and more recently (see Journal of Scottish Meteorological Society, vol. v. pp. IO3 and 348), showed that even for moderate heights the old notion of assuming the wind to be of uniform velocity at all altitudes was seriously in error, and that to rely upon it in the case of lofty structures might entail disastrous consequences.

While Mr. Stevenson's experiments have shown that the wind's velocity increases very considerably, especially near the surface, they do not touch the question of the increase noticed at great heights, nor can the formulæ or conclusions derived from them be said to throw any light on a matter which evidently contains the germs of many important truths for the meteorologist.

Where the engineer ends in fact the meteorologist may be said to begin; but in this case the engineer ends a little too soon, since Mr. Stevenson's latest experiments terminate at the top of a pole only 50 feet high, where he leaves us with a formula "believed to be sufficiently accurate for practical purposes," and which is said to give the velocity for "great heights" above sea-level." Whence Mr. Stevenson obtains this formula, or on what data he believes it to be approximately correct, we are not told, and here the question is left in a state of uncertainty for greater heights, in which we trust neither engineers nor meteorologists will allow it long to remain. It might even be advantageous to the former, if instead of trusting to a few empirical formula, they would ask the meteorologists what they knew about the matter, and joined with them in endeavouring to discover a rational formula which would yield satisfactory results at all elevations.

Theoretically the main factor at small elevations in determining the increase of velocity, would appear to be the diminution of friction as we rise above the surface, and as this must occur most decidedly near the surface, so the velocity must increase in the first few feet "per saltum." Mr. Stevenson's experiments and curves show this very clearly. Indeed up to a height of 15 feet the increase is so sudden, so irregular, and so clearly dependent on the nature of the surface, that no attempt has been made to include this space within a formula.

There is, however, another factor which acts positively in the same direction, and which, while operating for the most part at great heights, where its influence ultimately predominates to the exclusion of the friction factor, must be felt to some extent at comparatively moderate elevations.

I allude to the general increase in the barometric 